\title{
Urgences
}

\section{Il rasa sa passeuse...}

\section{André Brochu}

Numéro 15, octobre 1986

Épigraphiques

URI : https://id.erudit.org/iderudit/025327ar

DOI : https://doi.org/10.7202/025327ar

Aller au sommaire du numéro

Éditeur(s)

Urgences

ISSN

0226-9554 (imprimé)

1927-3924 (numérique)

Découvrir la revue

Citer ce document

Brochu, A. (1986). Il rasa sa passeuse... Urgences, (15), 64-64.

https://doi.org/10.7202/025327ar

Ce document est protégé par la loi sur le droit d'auteur. L'utilisation des services d'Érudit (y compris la reproduction) est assujettie à sa politique d'utilisation que vous pouvez consulter en ligne.

https://apropos.erudit.org/fr/usagers/politique-dutilisation/
Cet article est diffusé et préservé par Érudit.

Érudit est un consortium interuniversitaire sans but lucratif composé de l'Université de Montréal, l'Université Laval et l'Université du Québec à Montréal. Il a pour mission la promotion et la valorisation de la recherche. https://www.erudit.org/fr/ 


\section{André Brochu}

Il passa sa vareuse, dont il ne boutonnait jamais le col, tendit à Kyo le veston de sport accroché à une chaise...

André Malraux: la Condition humaine

Il rasa sa passeuse, dont il ne contournait jamais le bol, rendit à Viau le feston de mort arraché à une glaise.

Puis il passa à l'arroseuse qu'il ne détournait jamais du sol, pendit au seau le bouton cadavérique qui glissait sinistrement à l'extrémité du réfrigérateur devenu démesurément capable de toutes les inepties de tous les reproches déveines vengeances athlétiques catalepsies par-dessus le marché et tous les zigomènes les phytoptrons ameuglés si lazglamène etlisaptabédons car car il ne boutonnait jamais le col tendit à Kyo levestondesportaccrochéàunechaise 